\title{
Parenteral Fluid Therapy Following Cardiac Surgery in Ghildhood
}

\author{
Yoshiaki Tsuchida, M.D., Toshio Nakajo, M.D., Masao Hanawa, M.D., \\ Shigenori Sawaguchi, M.D., Masanobu Ismida, M.D., * \\ and Masahiro Saigusa, M.D.**
}

\begin{abstract}
SUMMARY
Water and electrolyte balance studies were carried out for 48 hours after operations in small children, who underwent cardiac surgery with or without extracorporeal circulation.

Insensible water loss, obligatory urine water and minimum requirement of water were determined. Serum osmolarity and body weight changes in relation to water intake were examined. An adequate dose of water was concluded to be $1,100 \mathrm{ml} . / \mathrm{M}^{2} /$ day to $1,400 \mathrm{ml} / \mathrm{M} .{ }^{2} /$ day in the first postoperative day and $1,000 \mathrm{ml} . / \mathrm{M}^{2} /$ day to $1,400 \mathrm{ml} . / \mathrm{M} .{ }^{2} /$ day in the second postoperative day.

Serum $\mathrm{Na}, \mathrm{K}$ and $\mathrm{Cl}$ concentration values were within or close to normal range throughout these studies. Interrelations between intake and gain-or-loss of electrolytes ( $\mathrm{Na}, \mathrm{K}$ and $\mathrm{Cl}$ ) were examined. It was found that sodium and chloride intake up to $40-50 \mathrm{mEc} . / \mathrm{M} .{ }^{2} /$ day are advisable.
\end{abstract}

\section{Additional Indexing Words :}

Water Electrolyte Balance study Insensible water loss Maintenance dose Extracorporeal circulation Hemodilution Pulmonary edema

7 HE purpose of this investigation was to determine suitable parenteral 1 administration of water and electrolytes following cardiac surgery. The study included cases with and without extracorporeal circulation in early childhood.

Overhydration should be avoided after cardiac operation. However, in small children too scvere limitation of parenteral fluids will result in metabolic disturbances from dehydration. Because of this, administration of some excess water is advisable, if we can do so safely. So, the prime purpose of this investigation centered upon the measurement not only of minimum require-

From the Second Department of Surgery and the Department of Thoracic Surgery, Faculty of Medicine, Unjversity of Tokyo, Tokyo.

* Associate Professor, Department of Surgery

** Professor, Department of Thoracic Surgery

Received for publication July 6, 1968. 
ments, ${ }^{1)}$ but also of the maximum dose of water, which can be safely given.

Administration of sodium or potassium to post-cardiac-surgery patients has been recommended by some authors, ${ }^{2)-4}$ ) but advised against by others. ${ }^{1}$ ) But no balance study has been performed to determine the daily optimal dose of electrolytes after cardiac surgery.

\section{Materials and Methods}

The subjects of this investigation were 20 children, 9 months to 9 years of age, who weighed $5.6 \mathrm{Kg}$. to $18.5 \mathrm{Kg}$. and whose body surface area ranged between 0.31 $\mathrm{M.}^{2}$ and $0.83 \mathrm{M}^{2}$ Extracorporeal circulation was used in 11 children, and the 9 underwent cardiovascular operations without the pump-oxygenator.

In cases with extracorporeal circulation, a moderate degree of hemodilution was obtained with Ringer's solution: Metabolic acidosis was corrected by 7 per cent sodium bicarbonate solution. Through extracorporeal circulation, $98 \%$ oxygen $-2 \%$ carbon dioxide gas was used in oxygenation and the patients were cooled down to $26^{\circ} \mathrm{C}-32^{\circ} \mathrm{C}$ esophageal temperature.

All balance studies were carried out in the Thoracic Surgery Department of the Tokyo University Hospital between October, 1964 and September, 1966, during which time no remarkable alternation was made in techniques of the perfusion and the operation.

Each patient was studied for 48 hours from the end of the operation and attended at all times during the study by one of the authors. Throughout the study, each patient was kept in an oxygen tent with 70 to 85 per cent humidity and $18^{\circ} \mathrm{C}$ to $22^{\circ} \mathrm{C}$ temperature.

Each patient was weighed before and at the end of operation and 24 and 48 hours after the end of operation. Appropriate deductions were made for urine in the bladder, thoracic catheters, bandages and clamps used to occlude the catheters during weighing. Both in the operating room and the recovery ward, body weights were determined on the same scale, suitable for children under $20 \mathrm{Kg}$. of weight.

Blood was drawn from each patient before, during and at the end of operation and 2, 6, 24 and 48 hours after the end of operation. Each blood sample was used to determine hematocrit, plasma protein, serum $\mathrm{Na}, \mathrm{K}$, Cl concentration values and serum osmolarity.

Urine was collected by spontaneous urination or catheter sampling. Catheter urine was obtained every 3 or 4 hours in cases of female children. The volume and specific gravity of urine were measured and thereafter urinary osmolarity and $\mathrm{Na}, \mathrm{K}$ and $\mathrm{Cl}$ concentrations were determined.

Stool did not occur during the study of any patient in this series. Small amounts of vomitus were estimated and, when larger, volumes were measured and $\mathrm{Na}, \mathrm{K}$ and $\mathrm{Cl}$ concentrations were determined.

Drainage from mediastinal spaces, thoracic and pericardial cavities was collected in glass cylinders calibrated in $5 \mathrm{ml}$. increments and regarded as blood loss of the same constitution as the circulating blood. Throughout the study, blood from tube-drainage and that drawn for examination was replaced volumetrically by blood preserved in ACD solution, which was calculated as 4 parts of blood and 1 
Table I. Multiple Electrolyte Solution and Standard Maintenance Dose of Water and Electrolyte

\begin{tabular}{|c|c|c|}
\hline & \multicolumn{2}{|c|}{ Multiple Electrolyte Solution } \\
\hline & Solution A & Solution B \\
\hline Sodium & $30 \mathrm{mEq} \cdot / \mathrm{L}$ & $35 \mathrm{mEg} \cdot / \mathrm{L}$. \\
\hline Potassium & 0 & $20 \mathrm{mEq} / / \mathrm{L}$ \\
\hline Chloride & $20 \mathrm{mEq} / \mathrm{L}$ & $35 \mathrm{mEq} \cdot / \mathrm{L}$ \\
\hline Lactate & $10 \mathrm{mEq} / \mathrm{L}$. & $20 \mathrm{mEq} . / \mathrm{L}$. \\
\hline \multirow[t]{3}{*}{ Glucose } & $4.3 \mathrm{~W} / \mathrm{V} \%$ & $4.3 \mathrm{~W} / \mathrm{V} \%$ \\
\hline & \multicolumn{2}{|c|}{ Standard Maintenance Dose } \\
\hline & First Postoperative Day & $\begin{array}{l}\text { Second Postoperative } \\
\text { Day }\end{array}$ \\
\hline Water & $1,200 \mathrm{ml} / \mathrm{M} .^{2} / \mathrm{day}$ & $1,500 \mathrm{ml} / \mathrm{M} . / \mathrm{day}$ \\
\hline Sodium & $36 \mathrm{mEq} / \mathrm{M} \cdot{ }^{2} /$ day & $52.5 \mathrm{mEq} . / \mathrm{M}^{2} /$ day \\
\hline Potassium & 0 & $30 \mathrm{mEq} . / \mathrm{M} \cdot 2 /$ day \\
\hline Chloride & $24 \mathrm{mEq} \cdot / \mathrm{M} \cdot{ }^{2} / \mathrm{day}$ & $52.5 \mathrm{mEq} / \mathrm{M} \cdot{ }^{2} /$ day \\
\hline
\end{tabular}

part of ACD solution.

Surface area was calculated from the equation of Du Bois and Du Bois. ${ }^{5)}$ All data in this study are expressed in terms of 1 M. ${ }^{2}$ body surface per 24 hours.

Multiple electrolyte solution was given by an intravenous catheter at approximately the same rate through 24 hours. Solution A (Table I) was given on the first postoperative day at a standard maintenance rate of $1,200 \mathrm{ml} . / \mathrm{M} .{ }^{2} /$ day and Solution $\mathrm{B}$ was given on the second postoperative day at a standard maintenance rate of $1,500 \mathrm{ml} / \mathrm{M} .2 /$ day. Peroral intake of water and electrolytes was not allowed in any cases on the first postoperative day and in a few patients small amounts of Solution B were given orally on the second postoperative day. The volume of administered fluid was measured by the scale on the side of the bottle, the accuracy of which was checked by a glass cylinder afterwards. The volume of each injection such as cardiotonics, antibiotics, hemostatics and analgesics was recorded and $\mathrm{Na}, \mathrm{K}$ and $\mathrm{Cl}$ concentrations were determined. Electrolytes in these injections were of considerable amounts.

\section{Calculations}

All water given parenterally (Solution A, Solution B, injections, ACD solution and plasma component of ACD preserved blood) and given orally (Solution B) are calculated as total intake of water. All sodium in solutions above is calculated as total intake of sodium.

Water or sodium in vomitus and plasma component of blood loss are abnormal loss of water or sodium. Maintenance dose of water or sodium, which is more important than total intake in analysing water and electrolyte metabolism, was calculated as the following. 

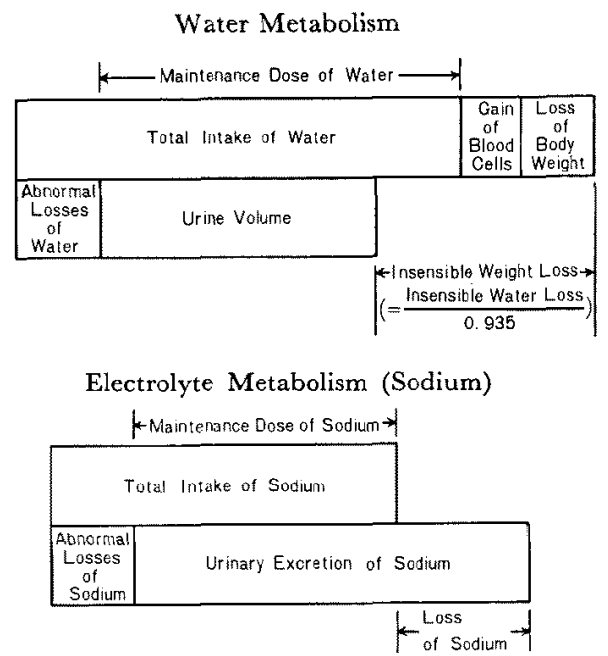

Fig. 1. Calculations.

Maintenance Dose of Water

$=$ Total Intake of Water-Abnormal Loss of Water

Maintenance Dose of Sodium

$=$ Total Intake of Sodium-Abnormal Loss of Sodium

Gain or loss of sodium ( $\mathrm{Na}$ balance) was calculated from the following equation (Fig. 1).

Gain or Loss of Sodium ( $\mathrm{Na}$ balance)

= Maintenance Dose of Sodium-Urinary Excretion of Sodium

The same calculation was made in the metabolism of potassium and chloride.

Insensible water loss was assumed to be 93.5 per cent of the insensible weight loss, ${ }^{61,7)}$ which was calculated as in Fig. 1.

Urinary excretion of solute was calculated by multiplying the urine volume (ml.) by the urine osmolarity (mOsm./L.).

Urinary Excretion of Solute

$=$ Urine Volume $(\mathrm{ml}$.$) \times Urine Osmolarity (\mathrm{mOsm} . / \mathrm{L}$.

Obligatory urine watcr was calculated on the assumption that the average maximal concentration of urine is $1,000 \mathrm{mOsm}$. $/ \mathrm{L}$. in postoperative periods. The equation is thus,

Obligatory Urine Water ( $\mathrm{ml}$.) $=$ Urinary Excretion of Solute $(\mathrm{mOsm}.) \times 1(\mathrm{ml} . / \mathrm{mOsm}$.

Osmolarity of serum and urine was determined by freezing point depression ${ }^{8)}$ with an advanced osmometer. Sodium and potassium were determined by Hitachi photo-electric spectrophotometer, and chloride by Schales and Schales' method.9)

\section{Results}

\section{Water Metabolism}

1) Serum Osmolarity and Serum $\mathrm{Na}$

Serum osmolarity during operation was high in patients with the pump- 

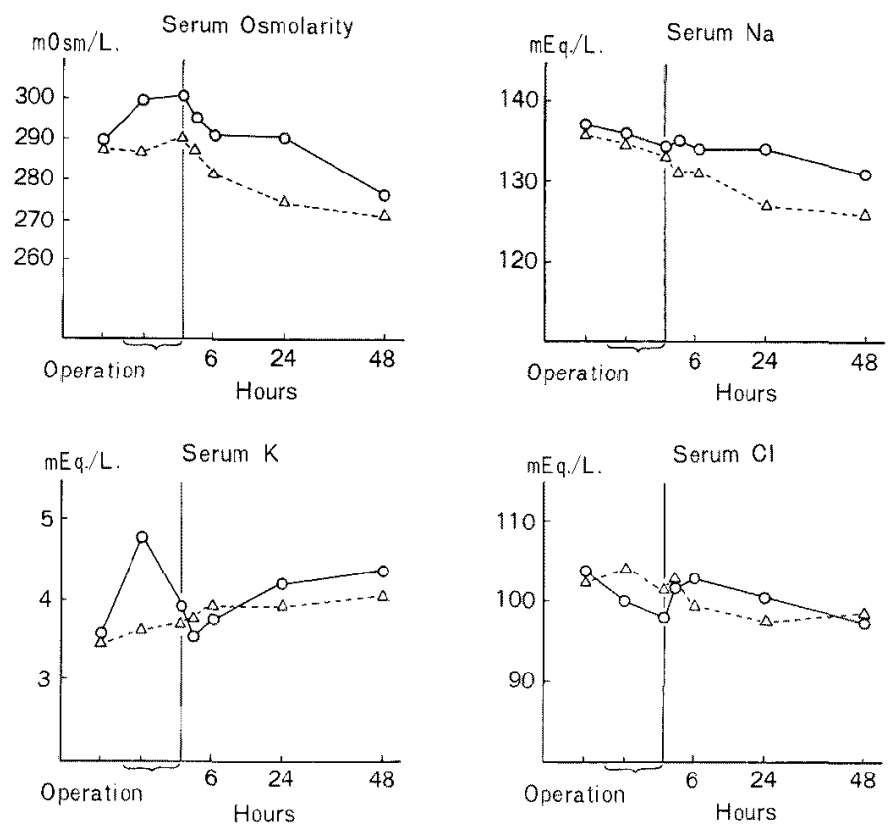

0 Average of 10 cases operated with pump-oxygenator

$\triangle--\triangle$ Average of 8 cases operated without pump-oxygenator

Fig. 2. Changes in serum osmolarity and $\mathrm{Na}, \mathrm{K}$ and $\mathrm{Cl}$ concentrations.

Table II. Insensible Water Loss, Obligatory Urine Water and Minimum Requirement of Water

(ml./M.2/day)

\begin{tabular}{|c|c|c|c|c|c|c|}
\hline & \multicolumn{3}{|c|}{ First Postoperative Day } & \multicolumn{3}{|c|}{ Second Postoperative Day } \\
\hline & $\begin{array}{c}\text { Insensible } \\
\text { Water } \\
\text { Loss }\end{array}$ & $\begin{array}{l}\text { Obligatory } \\
\text { Urine } \\
\text { Water }\end{array}$ & $\begin{array}{c}\text { Minimum } \\
\text { Requirement } \\
\text { of Water }\end{array}$ & $\begin{array}{c}\text { Insensible } \\
\text { Water } \\
\text { Loss }\end{array}$ & $\begin{array}{c}\text { Obligatory } \\
\text { Urine } \\
\text { Water }\end{array}$ & $\begin{array}{l}\text { Minimum } \\
\text { Requirement } \\
\text { of Water }\end{array}$ \\
\hline $\begin{array}{l}\text { With } \\
\text { Perfusion }\end{array}$ & $689 \pm 83^{*}$ & $626 \pm 199^{*}$ & $1,045 \pm 247 *$ & $566 \pm 164^{*}$ & $586 \pm 104 *$ & $882 \pm 225^{*}$ \\
\hline \multirow[t]{2}{*}{$\begin{array}{l}\text { Without } \\
\text { Perfusion }\end{array}$} & $839 \pm 196^{*}$ & $631 \pm 122^{*}$ & $1,200 \pm 236^{*}$ & $747 \pm 300^{*}$ & $615 \pm 158^{*}$ & $1,091 \pm 311^{*}$ \\
\hline & $755 \pm 159 *$ & $628 \pm 167^{*}$ & $1,114 \pm 246 *$ & $650 \pm 246^{*}$ & $600 \pm 128^{*}$ & $980 \pm 275^{*}$ \\
\hline
\end{tabular}

(* is $\sqrt{\mathrm{U}^{2}}: \mathrm{U}^{2}=$ Universal variation of the sample)

oxygenator (Fig. 2). Postoperatively serum osmolarity as well as serum sodium concentration decreased gradually in both groups. Postoperative decrease of serum $\mathrm{Na}$ and osmolarity was larger in patients without perfusion than in those with it.

2) Minimum Requirement of Water

Minimum requirement of water was calculated by the following equation. 


$$
\text { M.R.W. =I.W.L.+O.U.W.-M.W. }
$$

,where M.R.W. represents the minimum requirement of water, I.W.L. the insensible water loss, O.U.W. the obligatory urine water and M.W. the metabolic water. Abnormal losses such as naso-gastric suctions were replaced each time by a fluid of the same constitution and so should not be included in calculation of the minimum requirement of water.

The insensible water loss was determined by the calculation above (Fig. 1). As Table II shows, the mean value of insensible water loss in patients without pump-oxygenator was larger than in those with it, but the difference is statistically insignificant.

I.W.L. in the 1st postoperative day $755 \pm 159 * \mathrm{ml} . / \mathrm{M.}^{2} / \mathrm{day}$

I.W.L. in the 2nd postoperative day $650 \pm 246 * \mathrm{ml} . / \mathrm{M.}^{2} / \mathrm{day}$

The obligatory urine water was calculated from urinary excretion of solute.

O.U.W. in the 1st postoperative day

O.U.W. in the 2nd postoperative day

$$
628 \pm 167 * \mathrm{ml} . / \mathrm{M} .^{2} / \mathrm{day}
$$$$
600 \pm 128 * \mathrm{ml} . / \mathrm{M} .^{2} / \text { day }
$$

Metabolic water was assumed to be $270 \mathrm{ml} . / \mathrm{M}^{2} /$ day. $^{10}$ )

Minimum requirement of water was obtained by substituting into the equation the data above.

M.R.W. in the 1st postoperative day

M.R.W. in the 2nd postoperative day

$$
\begin{array}{r}
1,114 \pm 246 * \mathrm{ml} . / \mathrm{M} .{ }^{2} / \mathrm{day} \\
980 \pm 275 * \mathrm{ml} . / \mathrm{M} .{ }^{2} / \mathrm{day}
\end{array}
$$

The difference in minimum requirement of water between the patients with pump-oxygenator and those without it, or between the first and second postoperative day, was not statistically significant.

3) Upper Limit of Water Intake

The data above refer to the minimum dose of water required. Water intake less than this amount will result in metabolic deterioration from dehydration. So, from a practical standpoint, administration of some excess water is advisable, if it can be done safely.

The interrelation of serum osmolarity and maintenance dose of water is shown in Fig. 3. Serum osmolarity was higher in cases of smaller maintenance doses of water, whereas levels of less than $270 \mathrm{mOsm}$./L. of serum osmolarity were seen when the maintenance dose of water was larger than $1,400 \mathrm{ml} . / \mathrm{M} .{ }^{2} / \mathrm{day}$.

Body weight changes and maintenance dose of water are shown in Fig. 4. Body weights without urine in bladder were compared. Weight gains were

\footnotetext{
* is $\sqrt{u^{2}:} u^{2}=$ universal variation of the sample
} 


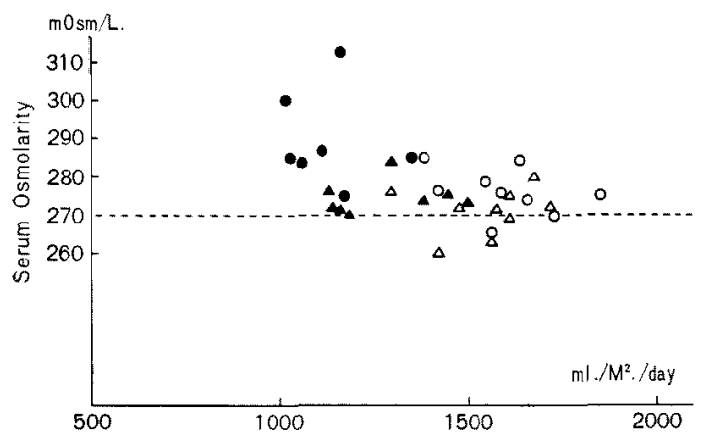

- First postop. day after perfusion Second postop. day after perfusion

$\Delta$ First postop. day without perfusion $\triangle$ Second postop. day without perfusion

Maintenance Dose of Water

Amount of water given as maintenance therapy

Fig. 3. Relationship between amount of water given and serum osmolarity.

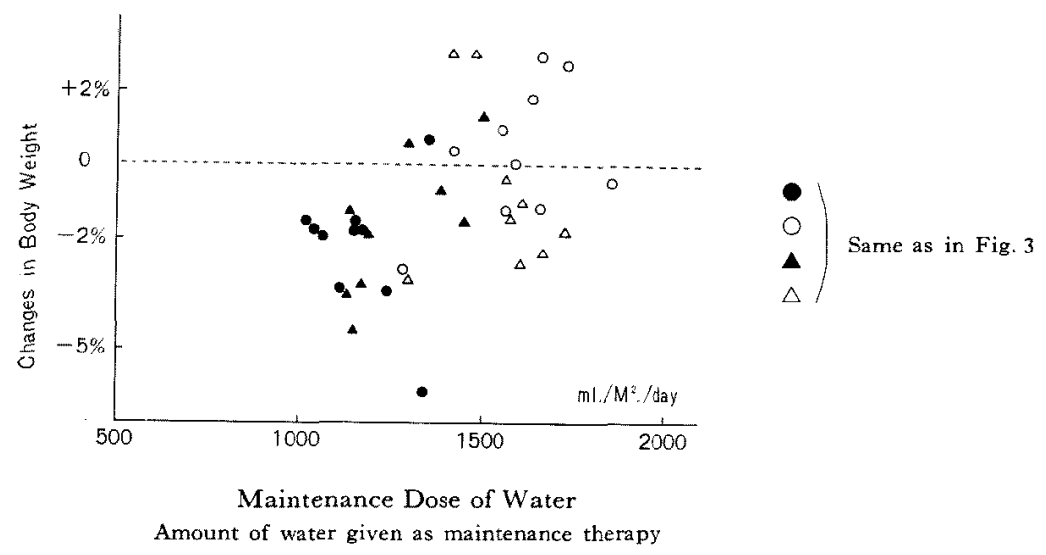

Fig. 4. Relationship between amount of water given and the percentage change in body weight.

observed when the maintenance dose of water was larger than $1,400 \mathrm{ml} . / \mathrm{M} .2 /$ day. It was therefore concluded that water intake should be less than $1,400 \mathrm{ml} . / \mathrm{M} .{ }^{2} /$ day.

Among the harmful effects of overintake of water, pulmonary edema is most feared after cardiac surgery. In 2 cases of this study, pulmonary edema occurred because of extraordinarily large amounts of blood or fluid administered during operation. During the postoperative course in these cases, water was restricted to $1,339 \mathrm{ml} . / \mathrm{M} .{ }^{2} /$ day or $1,017 \mathrm{ml} . / \mathrm{M} .{ }^{2} /$ day and a few hours later pulmonary edema subsided without any recurrence. In the other 18 cases given from $962 \mathrm{ml} . / \mathrm{M}^{2} /$ day to $1,859 \mathrm{ml} . / \mathrm{M} .{ }^{2} /$ day of water, no pulmonary edema was seen. So it was concluded that a water intake of less than $1,400 \mathrm{ml} . / \mathrm{M}^{2} /$ day was safe if it was given at approximately the same rate throughout 24 hours. 
4) Conclusions

The appropriate maintenance dose of water is $1,100 \mathrm{ml} . / \mathrm{M} .{ }^{2} /$ day to $1,400 \mathrm{ml} . / \mathrm{M} .{ }^{2} /$ day in the first postoperative day and $1,000 \mathrm{ml} . / \mathrm{M} .{ }^{2} /$ day to $1,400 \mathrm{ml} . / \mathrm{M} .{ }^{2} /$ day in the second postoperative days.

Electrolyte Metabolism

Approximately the same dose of electrolytes were given to both groups with and without extracorporeal circulation.

1) Serum $\mathrm{Na}, \mathrm{K}$ and $\mathrm{Cl}$ Concentration Values

The serum sodium concentration values, which largely reflect water metabolism, were parallel to serum osmolarity and showed a gradual decrease during the first and second postoperative days (Fig. 2).

Serum potassium concentration values in patients without extracorporeal circulation showed a gradual increase during the first and second post-operative days. In children with extracorporeal circulation, serum potassium concentration values were higher during perfusion. They showed slight hypokalemia 2 or 6 hours after operation, but thereafter a gradual increase was observed during the first and second postoperative days (Fig. 2). However, these serum electrolyte values remained within or close to normal range in all subjects.

2) Maintenance Dose and Gain or Loss of Electrolytes

In Fig. 5, interrelations are shown between maintenance dose and gain or loss (=balance) of electrolytes. When the maintenance dose of sodium was larger, sodium accumulation occurred, whereas the balance was negative on smaller maintenance doses of sodium. From these data, it was concluded that

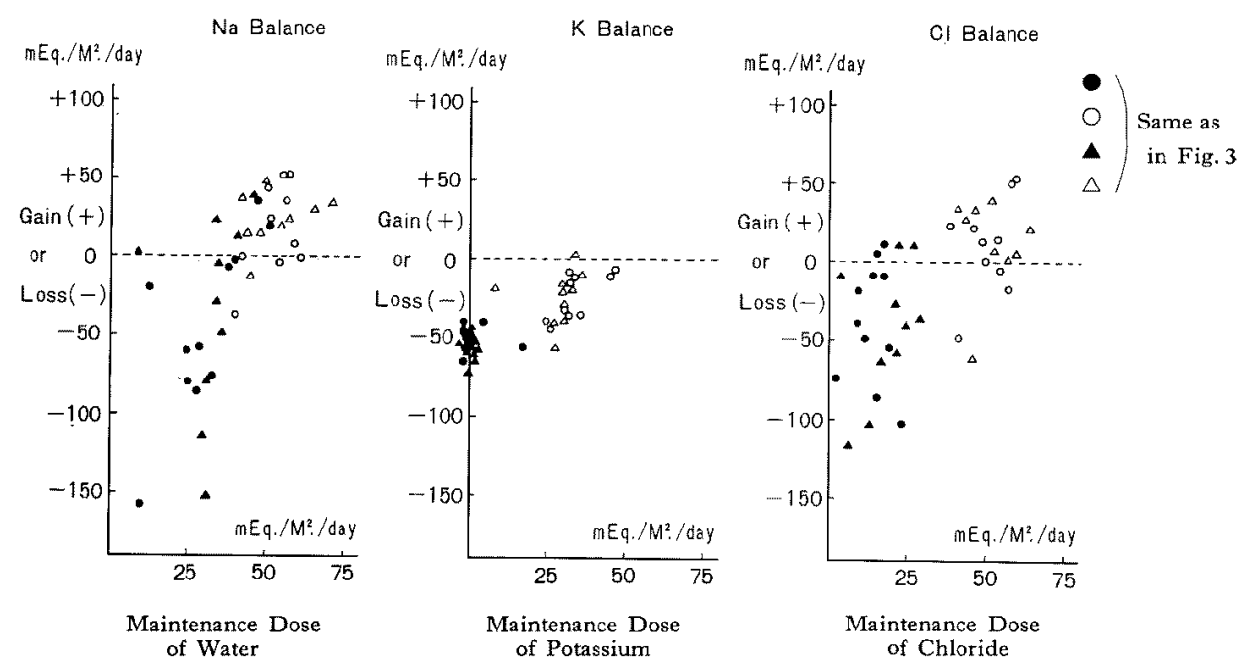

Fig. 5. Relationship between maintenance dose and gain or loss (balance) of sodium, potassium and chloride. 
the appropriate dose of sodium is $40-50 \mathrm{mEq} . / \mathrm{M} .{ }^{2} / \mathrm{day}$, on the assumption that the maintenance dose should be the same as output.

In the first postoperative day, potassium balance showed an average loss of $50 \mathrm{mEq} / \mathrm{M} .{ }^{2} /$ day, because no potassium was given during this severely ill period. During the second postoperative day, about $30 \mathrm{mEq} / \mathrm{M} .{ }^{2} /$ day of potassium was given, and the potassium balance was still negative. More potassium may be given, but it is difficult to standardize the daily maintenance dose of potassium, because hyperkalemia was often seen in patients with circulatory failure.

Chloride balance in relation to chloride maintenance dose is also shown in Fig. 5. An appropriate dose of $40-50 \mathrm{mEq} . / \mathrm{M} .{ }^{2} /$ day was concluded on the basis of identical results as those found with sodium metabolism.

\section{Discussion}

In 1957, Sturtz and his associates ${ }^{1 /}$ carried out 21 balance studies in children after open heart surgery and gave $493 \mathrm{ml} . /$ M. $^{2} /$ day and $765 \mathrm{ml} . / \mathrm{M} .{ }^{2} /$ day of minimum water requirement (Table III). When the maintenance dose of water is discussed, abnormal losses should be excluded in calculation-there must be clear distinguishment between maintenance therapy and abnormal loss therapy. ${ }^{11)-13)}$ So, their data could be regarded as $493 \mathrm{ml} . / \mathrm{M} .{ }^{2} /$ day and $615 \mathrm{ml} . /$ M. ${ }^{2} /$ day of minimum water requirement (minimum maintenance dose of water). Comparing our data with Sturtz's investigation in Table III, a large difference is found especially in insensible water loss and obligatory urine water.

As for insensible water loss calculated in this investigation, the following 2 factors have to be kept in mind.

1) Younger children were studied.

2) Oxygen tents with 70-85 per cent humidity were employed, whereas

Table III. Minimum Requirement of Water

\begin{tabular}{|c|c|c|c|c|}
\hline & \multicolumn{2}{|c|}{ Data in This Investigation } & \multicolumn{2}{|c|}{ Sturtz et al. ${ }^{1)}$} \\
\hline & $\begin{array}{c}\text { First } \\
\text { Postoperative } \\
\text { Day }\end{array}$ & $\begin{array}{c}\text { Second } \\
\text { Postoperative } \\
\text { Day }\end{array}$ & $\begin{array}{c}\text { First } \\
\text { Postoperative } \\
\text { Day }\end{array}$ & $\begin{array}{c}\text { Second } \\
\text { Postoperative } \\
\text { Day }\end{array}$ \\
\hline (1) Insensible Water Loss & 755 & 650 & 469 & 420 \\
\hline (2) Obligatory Urine Water & 628 & 600 & 294 & 465 \\
\hline (3) Abnormal Losses & - & - & 0 & 150 \\
\hline (4) Metabolic Water & 270 & 270 & 270 & 270 \\
\hline $\begin{array}{l}\text { (5) Minimum Requirement } \\
\text { of Water }\end{array}$ & $\begin{array}{l}(5)=(1)+ \\
1,114\end{array}$ & $(2)-(4)$ & $(5)=(1)+(2$ & $+(3)-\frac{(4)}{765}$ \\
\hline
\end{tabular}


in Sturtz's studies ${ }^{1)}$ the tent was filled with water mist.

Insensible water loss obtained in this investigation is more physiological and more closely approximates to Heeley-Talbot's equation. ${ }^{14)}$

Obligatory urine water reflects urinary excretion of solute. Even with appropriate deduction of solute intake due to low-electrolyte solution used in this investigation, urinary excretion of solute in the first postoperative day is much larger than that in Sturtz's studies. ${ }^{1)}$ This probably is explained by the difference in the methods of the perfusion, such as hemodilution, rate of perfusion and so forth.

With these considerations, it is found that the minimum requirement of water varies with the age of the patient, humidity in the oxygen tent, method of perfusion and solutions used in parenteral fluid therapy, and so it should be determined in each Cardiovascular Surgical Unit respectively. The minimum requirement of water discussed above should be considered to be the lower limit from a clinical standpoint. Some patients, who were given water in amounts close to the minimum requirement, not only complained of severe thirst, but also demonstrated clinical sings of dehydration in skin and oral mucosa. In small children, who need adequate hydration, the maintenance dose of water should be near $1,400 \mathrm{ml} . / \mathrm{M}^{2} / \mathrm{day}$. As was shown in this investigation, on a maintenance dose of water near $1,400 \mathrm{ml} . / \mathrm{M}^{2} / \mathrm{day}$, no postoperative pulmonary edema developed. From the standpoint of water metabolism, there must be clear distinguishment between the postoperative cardiac patients with good cardiac output and those with circulatory failure. The latter can be diagnosed by urine volume, urinary osmolarity and clinical signs. ${ }^{151,16)}$ If circulatory failure is ruled out, it is safe and advisable to use maintenance doses of water up to $1,400 \mathrm{ml} . / \mathrm{M}^{2} / \mathrm{day}$.

Postoperative hyponatremia-hyperkalemia was observed in this investigation (Fig. 2). This seems to correspond to the post-traumatic Na-K shift ${ }^{17}$ ) noted in general surgery. Although the precise mechanism of this hyponatremia is not clearly understood, dilution by sodium free metabolic water and low electrolyte parenteral fluid is thought to be of primary importance. For example, if we had used only 5 per cent glucose solution in these balance studies, more marked hyponatremia supposedly would have been seen. So it was felt advisable to use some sodium postoperatively. As has been demonstrated in postoperative patients after general surgery, ${ }^{18)}$ increased intake of sodium will cause sodium accumulation, whereas negative balance occurs if the parenteral sodium dose is too little. In this investigation it was found that parenteral administration of $40-50 \mathrm{mEq} . / \mathrm{M}^{2} /$ day of sodium does not cause negative or positive balance and sodium intake up to $40-50 \mathrm{mEq} . / \mathrm{M} .{ }^{2} /$ day seems to be a safe and advisable dose. 


\section{REFERENGES}

1. Sturtz, G. S., Kirklin, J. W., Burke, E. C., and Power, M. H.: Circulation 16: 988, 1957.

2. Schmidt-Mende, v. M.: Thoraxchirurgie 9: 90, 1961.

3. Norberg, B., Senning, A., and Tomaszewski, W.: Acta Chir. Scand. 120: 237, 1960.

4. Ebert, P. A., Jude, J. R., and Gaertner, R. A.: Circulation 31: Suppl. 137, 1965.

5. DuBois, D. and DuBois, E. F.: Arch. Int. Med. 17: 863, 1916.

6. Lcvinc, S. Z. and Marples, E.: Am. J. Dis. Child. 40: 269, 1930.

7. Newburgh, L. H. and Johnston, M. W.: Physiol. Rev. 22: 1, 1942.

8. Crawford, J. D. and Nicosia, A. P.: Lab. Clin. Med. 40: 907, 1952.

9. Schales, O. and Schales, S. Z. J.: J. Biol. Chem. 140: 879, 1941.

10. Talbot, N. B., Crawford, J. D., and Butler, A. M.: New Eng. J. Med. 248: 1100, 1953.

11. Butler, A. M. and Talbot, N. B.: New Eng. J. Med. 231: 585, 1944.

12. Holliday, M. A. and Seger, W. E.: Pediatrics 19: 823, 1957.

13. Nakajo, T., Ishida, M., Saito, S., Sawaguchi, S., Sato, T., Hanawa, M., Hori, T., and Tsuchida, Y.: presented on the 11 th International Congress of Pediatrics, Tokyo, Japan, 1965.

14. Heeley, A. M. and Talbot, N. B.: Am. J. Dis. Child. 90: 251, 1955.

15. Grismer, J. T., Levy, M. J., Lillehei, R. C., Indeglia, R., and Lillehei, C. W.: Surgery 55: $24,1964$.

16. Grismer, J. T., Rozelle, L. T., and Koch, R. B.: Dis. Chest 49: 467, 1966.

17. Moore, F. D.: Metabolic Care of Surgical Patient. W. B. Saunders Co., Philadelphia, 1959.

18. Border, J., Talbot, N. B., Terry, M., and Lincoln, G.: Metabolism 9: 897, 1960. 